\title{
The Influence of Destination Attributes and Quality of Experience on Return Visit Interest
}

\author{
${ }^{1}$ C. Catur Widayati; ${ }^{2}$ Dwi Sihono Raharjo; ${ }^{3}$ Wasbeka Abie Yuwono; \\ ${ }^{4}$ M. Rifky Setiawan \\ ${ }^{1,4}$ Faculty of Economics and Business, Universitas Mercu Buana, Jakarta, Indonesia \\ ${ }^{2}$ Faculty of Economics and Business, Universitas Persada Indonesia-YAI \\ Jakarta, Indonesia \\ email: dwisihono.raharjo@gmail.com; \\ ${ }^{3}$ Badan Narkotika Nasional , Jakarta Indonesia \\ email: abieyuwono@gmail.com \\ Correspondence author: christinewijaya73@yahoo.co.id/catur.widayati@mercubuana.ac.id
}

\begin{abstract}
This study aims to determine and analyze the Destination Attributes and Service Quality towards Return Visit Interest (Case Study of Floating Market Bandung). The research design used is casual research. The sampling technique used is non-probability sampling; the sampling technique used and suitable for this research is convenience sampling. Of the samples used are 125 samples meet the criteria. The data method uses a questionnaire. The findings in this study indicate that destination attributes have a positive and significant effect on return visit interest, and experience quality has a positive and significant effect on return visit interest.
\end{abstract}

Keywords: Destination Attributes, Service Quality, Return Visit Interest

DOI: $10.7176 / \mathrm{JTHS} / 59-03$

Publication date:December $31^{\text {st }} 2021$

\section{INTRODUCTION}

In the current era of globalization, tourism is developing and becoming a major topic throughout the world. The development of tourism is certainly in line with the development of technology and information, one of which is the presence of the internet. The internet creates an information system as if the world has no boundaries in space and time so that it allows for a more interactive communication process and helps people in all parts of the world to easily access and find out the information they want, including information about a tourist attraction in various parts of the world, including information about the attractions that Indonesia owns.

According to UNWTO (2013), tourists travel for at least 24 hours in the country visited, where the purpose of their visit is for vacation, recreation, health, study, religious purposes, sports, business, family affairs, and meetings. There are three methods of travel, namely traveling alone, in groups, or using a travel agency. Interesting experiences that tourists experience during their first visit to a tourist destination can generate interest in revisiting the same destination for their travels.

According to the Department of Tourism and Culture of West Java Province (2018), tourism is one of the important factors in the economic development of a region. Through the Department of Tourism and Culture, West Bandung Regency seeks to develop the tourism market and improve the quality of its services to tourists. The tourism activities offered by West Bandung Regency include nature tourism, historical tourism, cultural tourism, special interest tourism, culinary tourism, religious tourism, shopping tourism, and many other tourist activities. It has become an attraction for foreign and domestic tourists to visit.

Table 1 below shows that the number of tourists visiting West Java Province has decreased in 2017 and has increased again in the last year. West Java Province is in great demand by Indonesian tourists and foreign tourists. West Java, which has an area of about 35,222 km2 with the capital district of West Bandung, is a province that is very attractive to tourists due to the friendliness of the local people and beautiful scenery. 
Table 1. Number of West Java Tourists in 2014-2018

\begin{tabular}{|c|c|c|c|}
\hline \multirow{2}{*}{ Year } & \multicolumn{2}{|c|}{ Tourists } & \multirow{2}{*}{ Number } \\
\hline & Overseas & Domestic & \\
\hline 2014 & 1.962 .639 & 47.992 .088 & 49.954 .727 \\
\hline 2015 & 2.027 .629 & 56.334 .706 & 58.362 .335 \\
\hline 2016 & 4.428 .094 & 58.728 .666 & 63.156 .760 \\
\hline 2017 & 2.945 .716 & 42.406 .484 & 43.703 .778 \\
\hline 2018 & 2.961 .283 & 48.215 .345 & 51.176 .628 \\
\hline
\end{tabular}

Source: West Java Tourism and Culture Office 2018

According to the Central Statistics Agency for West Java (2019), West Java Province has several cities and regencies, and there are 17 districts and nine cities in West Java. West Java Province is one of the most advanced provinces and a leading partner of the nation's capital, prioritizing the tourism sector as the most important part of regional development. By occupying a position as one of the main activities in the tourism sector business. West Java Province is expected to support the increase in West Java Regional Original Income.

Based on Table 2, there is a significant increase in the Bandung area, which has very attractive tourism potential. Seeing a large number of tourist visits to Bandung, this is a great opportunity to reach consumers.

Table 2. Number of Bandung International and Domestic Tourists

\begin{tabular}{ccc}
\hline Year & Tourists & Growth \\
\hline 2017 & 3.803 .892 & $40 \%$ \\
2018 & 5.847 .932 & \\
\hline
\end{tabular}

Source: Department of tourism and culture of West Java Province in 2018

In addition, the city of Bandung is a shopping paradise known as Paris Van Java. Paris Van Java has become a predicate that cannot be separated from the city of Bandung. History states that the title was given by European citizens who lived in Indonesia since the Dutch colonial era and made Paris Van Java the center of their activities, ranging from intellectual activities, arts, culture, and entertainment and recreation.

One of the areas in Bandung that provides a reference for interesting and unique tourist destinations in West Bandung Regency, so there is no doubt that tourism in West Bandung Regency is a new thing for tourists visiting West Java.

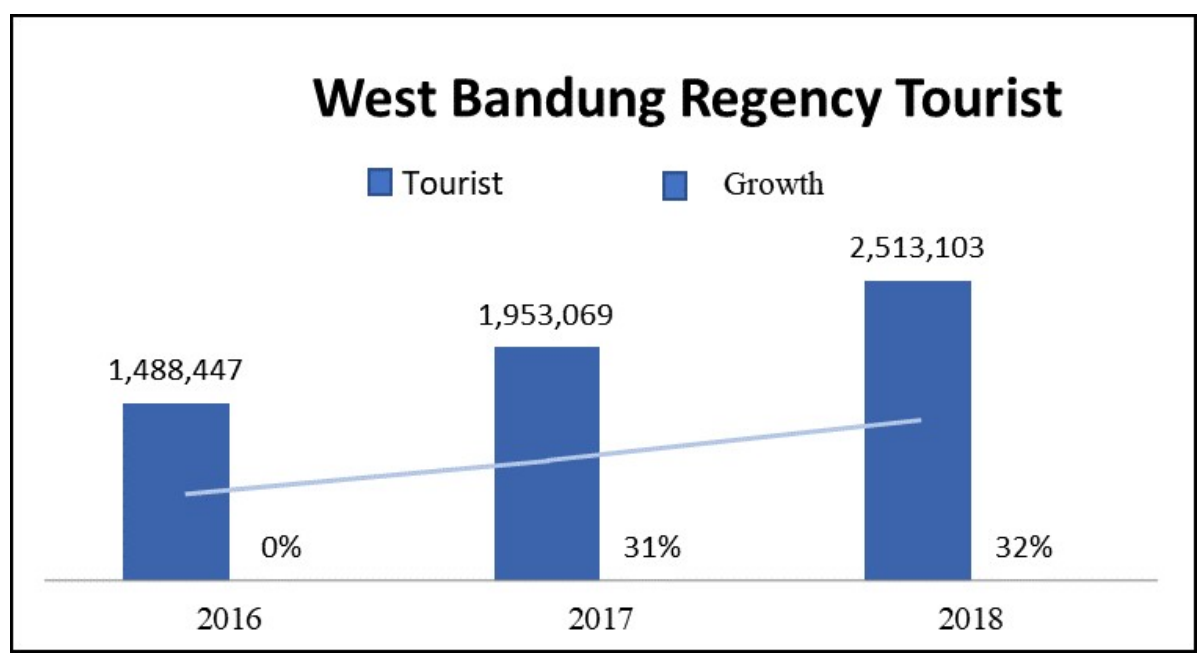

Figure 1. West Bandung Regency Tourists

Source: West Bandung Regency Culture and Tourism Office, 2019 
According to Faris (2015), marketers create products or services by touching the five senses of consumers, touching the hearts, and stimulating the minds of consumers by creating pleasant experiences and imprinting them in memory. If the product can touch the emotional value of the customer positively, it can be an unforgettable experience between the company and the customer. Conversely, if the experience obtained by consumers is less than pleasant, it will create a negative unforgettable experience. A positively unforgettable experience has a very good effect on tourist service providers because satisfied customers usually tell people about their experiences using the services of a company.

Based on Table 3, it is explained that the most preferred location is the Lembang area, with a total of 42 tourist sites in the West Bandung Regency area. A company with good tourism attributes with good experience quality then makes a tourist spot most likely to have loyal visitors. Understanding how visitor behavior will contribute to the company to formulate a marketing strategy that will later be implemented in introducing and promoting their tourism attributes to the market.

According to the West Bandung Regency Culture and Tourism Office (2019), in Table 3, when tourism attributes are about to be promoted, it has been known long before what the needs and desires of each customer are. As evidenced by the development of Bandung tourism trends, which are increasing, the location of the western part of Bandung is currently the most preferred choice. Here are some tourist sites in Lembang, Bandung. Lembang District is one area with the most tourist attractions because $25.64 \%$ of tourist attractions in the West Bandung Regency are in the Lembang District. Attractions in Lembang District include De Ranch, Maribaya, Floating Market, Cikole, Dusun Bambu, to the most recent one, the Farm House.

Table 3. West Bandung Regency Tourism Locations

\begin{tabular}{lc}
\hline \multicolumn{1}{c}{ Districts } & Total \\
\hline Lembang & 42 \\
Parongpong & 7 \\
Cisarua & 21 \\
Ngamprah & 2 \\
Padalarang & 2 \\
Cililin & 3 \\
Saguling & 2 \\
Cipatat & 7 \\
Cikalongwetan & 4 \\
Cipeundeuy & 1 \\
Rongga & 20 \\
Sindangkerta & 6 \\
Gununghalu & 16 \\
\hline Source: West Bandung Regency Culture and Tourism Office, 2019
\end{tabular}

The number of tourist attractions that are already quite a lot makes the competition in the tourism industry increasingly tight. It makes more urban tourism in Bandung, including culinary tourism, shopping tourism, and design tourism, which tightens competition in the tourism industry.

Based on the table, the four tourist sites in the Lembang area that are most in-demand are the floating market Lembang with a percentage of $21 \%$, then The Lodge Maribaya and Farmhouse with a percentage of 20\%, Dusun Bamboo tourist attractions have a percentage of $16 \%$ followed by Cikole with a percentage of $13 \%$. Furthermore, finally, De'Ranch has the lowest percentage of $10 \%$. Therefore, the writer chose the most popular location, namely Floating Market Bandung. 
Table 4. Lembang Bandung Tourism Locations

\begin{tabular}{clcc}
\hline No & \multicolumn{1}{c}{ Place } & Rating & Number of Ratings \\
\hline 1 & Floating Market & 4.9 & 51.153 \\
2 & De' Ranch & 4.0 & 25.124 \\
3 & Farm House & 4.5 & 49.213 \\
4 & Cikole & 4.1 & 32.741 \\
5 & The Lodge Maribaya & 4.6 & 50.381 \\
6 & Dusun Bambu & 4.0 & 39.260 \\
\hline
\end{tabular}

Source: Kompasiana (Accessed on April 24 2019, 10.00 WIB)

The number of alternative tourisms offered will affect the decision of tourists in visiting a tourist spot. Although the Lembang floating market has a different concept at the beginning of its emergence, is facing competition in the Lembang floating market tourism industry, it must have added value in offering its tourism products. In this case, the company must convince tourists to make purchasing decisions that are expected to increase the number of return visits, both in the short and long term. One strategy that can be used is to pay attention to the factors of the tourist destinations' attributes.

According to Kotler and Keller (2016), the attributes of tourist destinations include infrastructure, local culture, special activities and events, access, and local hospitality. Lembang's floating market has the attributes of a tourist destination that matches the expectations of tourists because the concept offered is very different from other competitors in the tourism sector. The infrastructure offered by the floating market is diverse and unique. Starting from the floating market, transactions using special coins, exploring the lake by boat, miniature gardens, and providing food for animals. The local culture is friendly to the tourists who visit. Access is very easy to reach by private vehicle or public transportation.

In creating a positive experience, stakeholders in the tourism sector continue to create innovations in presenting tourist attractions and attractions in West Java, especially in West Bandung Regency, to follow the mindset of tourists in changing their interest in tourism products. One of the newest tourist attractions in West Java, precisely in West Bandung Regency, is an artificial recreation park, Floating Market Lembang, or floating market. As the name implies, the advantages of the Lembang Floating Market compared to other tourist attractions are the floating market itself and a product whose function is the basic reason for consumers to buy it, these are snacks or food sold on boats which are served with a realistic view of the Lembang floating market lake which beautiful and cool climate.

The Floating Market Lembang tourist area is the newest tourist attraction present in West Bandung Regency with the concept of One-stop entertainment, where tourists can carry out culinary tourism activities and shop for souvenirs such as clothes accessories to adventure using canoes. This tourist destination opened on December 19, 2012. Initially, the Lembang Floating Market was only open on weekends, but now the Lembang Floating Market is open every day. The area used by the Lembang Floating Market is a natural lake called Situ Umar. Initially, Situ Umar was only used by the surrounding community as a fishing spot, but nowadays, Situ Umar has become an artificial tourist attraction with the concept of an artificial recreation park called Floating Market Lembang.

The quality of the experience when traveling is always a concern for every tourist attraction manager. The important factor for the sustainability of a company or tourist destination is the quality of the experience while traveling can increase the advantage in the competition. Tourists who are satisfied with the products and services provided tend to come back, which shows how important the quality of the experience is when traveling.

The quality of the experience when traveling is a key factor for managers to increase visits and attract tourists to come back. Kotler and Keller (2016) define the quality of experience as the level of one's feelings resulting from a comparison between reality and the expectations received from a product or service. If the perceived service performance is lower than expected, the consumer will feel disappointed. On the other hand, if the service perception meets or exceeds consumer expectations, consumers will feel satisfied, and there is a tendency for consumers to use the service provider again.

According to McCole (2015), currently, in purchasing a product, tourists not only see the functions and benefits of a tourist place, but tourists see how a tourist place provides emotional value in the minds of tourists. When the values offered by the company find a match in the minds of tourists, these values will bind the emotions of tourists and make tourists more loyal. These values make experience quality assessed as the right strategy in the world of modern competition.

Encouraged by a pre-survey carried out by the author where this pre-survey is to find out what factors make visitors make return visits following the author's questions, namely, destination attributes and quality of experience at Lembang tourist sites, namely the floating market. To strengthen this phenomenon, the researchers 
conducted a pre-survey distributed to respondents who had visited the Lembang Bandung floating market with a sample of 40 people and were taken randomly.

From the results of a pre-survey conducted on 40 respondents, it was found that the most dominating factor in visitors' interest in revisiting is the dimensions of the destination attribute. Strong destination attributes make visitors return to the Lembang floating marker. Besides that, the quality of the experience felt by the tourists is well created, which will make tourists choose to return to the Lembang floating marker. This research was conducted to prove that the attributes of the destination and the quality of the experience can influence the decision to revisit tourists in carrying out tourist activities.

According to Marinkovic et al., (2014), the intention to revisit a destination and provide positive word of mouth can be an important source of profitability or profit. Positive experiences can generate customer satisfaction, which can influence the decision to visit next (revisit intention). In increasing the revisit intention to a destination, researchers will identify the factors that determine the desire of tourists to visit again. In this case, the factors that influence revisit intention can be developed to increase the desire to visit again.

According to Nusantini (2016), destination attributes as system support and community values can influence repurchase intentions. Attributes that have a dominant influence as a shaper of tourist perceptions are the attributes of the atmosphere. Tourists travel looking for another atmosphere (ambiance) from their daily life, such as tranquility, entertainment, relaxation, and mingling and interacting with the local community around the destination location.

Faris (2015), in research on the quality of experience (experience quality), argues that a positive response affects repurchase intentions. The highest quality of experience in solving problems with service quality is because it has met consumer expectations for the quality of services provided by employees. While the lowest indicators are Value for time and competence, that is, there is still a lack of timeliness and competence from employees who are still lacking.

The problems in this study are: (1) Is there any influence of the Destination Attribute on the interest in returning visits to the Lembang Floating Market tourist spot? (2) Is there influence on the quality of experience on the interest in returning to the tourist attractions of the Lembang Floating Market?

The research objectives are, (a) to find out and analyze the influence of destination attributes on the interest in returning visits to the Lembang Floating Market tourist spot; (b) To find out and analyze the influence of the quality of experience on the interest in returning visits to the Lembang Floating Market tourist spot.

\section{LITERATURE REVIEW}

\section{Revisit to Intention}

Based on the novel tourism literature, research on tourists' intention to revisit different types of destinations has been a focus for some time (Lam and Hsu, 2006). It is a concept continuously studied by researchers, some of them being Som and Badarneh (2012), Hsieh (2013), Chang (2013), Munhurrun et al., (2014), Li (2014), Ayoun et al., (2014), Wang et al. (2015) and Thimusak and Rungkanjanases (2016) who had predicted and explained it in different types of destinations. Those researchers' overview pointed out that tourists' intention in re-visiting is being homologated as worth concept in predicting the future (Permana, D. (2018)

According to Chen and Tsai (2007), the definition of revisiting is the visitor's assessment of the suitability for revisiting the same destination or willingness to recommend a destination to others. The behavior of visitors can be observed from the process of setting goals, evaluating and planning future behavior. Meanwhile, according to Fitriyani (2014) stated that repeat visits are a concept of repurchase intentions derived from behavioral intentions. According to Yuniawati and Finardi (2016) explaining that revisit intention is the possibility of tourists to repeat activities or revisit a destination. If it is linked from a tourism point of view, it can be interpreted as the possibility to plan a return trip in the future.

While Lin and Liang (2011) in Kuo et al., (2012) define return visit interest as the willingness of consumers to buy the same product or service and it is a simple, objective predictor, and is an observable future buying behavior. Based on the above understanding, it can be interpreted that return visit interest is a customer behavior where customers respond positively to the quality of service and quality of experience so as to generate interest in revisiting a destination in the future.

According to Albarq (2014) the theory of visiting interest is analogous to buying interest, that tourist visit interest is the same as consumer buying interest. Understanding interest according to Kotler and Keller (2016) that interest is an encouragement, namely a strong internal stimulus that motivates action (statement of interest to revisit), where this impulse is influenced by positive stimuli and feelings about the product. In the study, the factor indicated as a stimulus that motivates purchase intention is the attribute of the destination to the quality of the experience felt by tourists.

Osti, Disegna, and Brida (2012) stated that loyalty and satisfaction could encourage an interest in revisiting. Repurchase interest is created because consumers feel that the quality of the product and the quality of service provided are according to what they expect to buy our products in the future. The arisen interest in 
buying creates motivation that is recorded in their mind, which at the end, when a consumer has to fulfill their need, will actualize what is in their mind.

\section{Destination Attribute}

According to Qomariyah (2017), Destination attributes, in other terms, are the main resource and attractor. These resources and key draws are the main elements of a destination's appearance. Destination attributes, in other words, are pull factors for tourists to destinations. The stronger the pull factor, the higher the desire of tourists to visit. Destination attributes, in other terms, as the main resource and attractor. These resources and key draws are the main elements of a destination's appearance. Destination attributes, in other words, are pull factors for tourists to destinations. The stronger the pull factor, the higher the desire of tourists to visit.

According to Reisinger (2009), one of the uses of destination attributes is for marketing needs. Perceptions of the international tourist market in choosing a destination can be examined through attributes. The destination attribute is a choice for tourists, and this means that if tourists want to visit, they will choose a destination that is suitable for their needs. Therefore, as an option, the destination will focus on which market to target in developing the destination following the desired destination attributes. For that, it is very important to reach this market.

Many researchers have carried out several empirical studies using destination attributes. Based on these studies, it can be seen that a destination will have potential according to the components of each research. Distinguishing one destination from another is the quality of the destination and the focus of which attributes are the emphasis for destination development and marketing. In addition, the packaging of the destination attributes has been done well to become a quality product for tourists.

So, it can be seen that one tourist destination and other tourist destinations have their characteristics or, in other words, have different destination attributes depending on the availability of superior attributes in each destination. In addition, not all destination attributes can attract tourists because some are unattractive. The destination attribute component described by Bajs (2011) in Nayon (2020) consists of two groups; this depends on the dimension of the destination attribute owned by the destination. The two groups consisted of a primary group and a secondary group. The primary group includes nature, culture, technology, and other elements of the destination environment. In contrast, the second group includes special features developed for tourism such as hotels, transportation, entertainment, and others.

Furthermore, according to Mill and Morrison (2012) in Pelu and Akbar's research (2019), those destination attributes are components that are mutually dependent on each other and form an experience for tourists. The components are the destination mix, which consists of tourist attractions, facilities, infrastructure, transportation, and hospitality.

According to Hasan (2015) in Mayasari and Budiatmoko's research (2016) states that the potential tourists considering all forms of visit, the product must be designed in a package consisting of tangible or intangible components, and the tourists must feel activities at the destination. Tourists as experiences that match market prices. According to Dwyer and Kim (2003), in the research of Khaeril et al., (2020). that source-destination attributes are divided into two types, namely attributes derived from inheritance and attributes created or created. Attributes derived from heritage include nature, such as mountains, lakes, beaches, rivers, weather), while cultural heritage includes culture, traditional food, language, handicrafts, traditional clothing, and belief systems.

\section{Experience Quality}

According to Gallan et al., (2013), experience quality is the evaluation of services provided by service providers and shaped by customers during the service process. Evaluation of services provided by service providers that are intangible as a whole of an organization. It focuses on how to provide services to consumers in the performance of services.

According to Palli and Mamila (2012), the quality of experience is a measurement of the service delivery process following the expectations of consumers, and the fulfillment of expectations from consumers will lead to customer satisfaction, wherein operant service quality is the process of service delivery through dynamic resources, namely human knowledge and skills. In the service sector, quality will be the dominant element for consumers in evaluating. Consumers assess service quality based on perceptions of outcome quality, interaction quality, and physical environment quality. According to Paramudita and Japarianto (2012) in their research, Safitri (2017), customer experience is an internal and subjective customer response due to direct or indirect interaction with the company. Senjaya (2013) describes five steps that companies must take in building customer experience: (1) Knowing customer desires; (2) Good processes and systems to meet all customer expectations; (3) Make customers happy and enjoy the transaction process; (4) Make customers feel "WOW."; (5) Make the customer success with the transaction. 
In general, according to Dyki and Sutrasmawati (2016), customer experience quality refers to the customer's perception itself and the interpretation of all aspects encountered when interacting or visiting a company or retail. Therefore, the customer experience in a company is not only about customers who want to buy a product but also about the atmosphere inside and outside the company or retail, and even other customers. It is a design from a company's management to provide stimulation and attention to visitors and customers so that they have experience quality and memories of a company itself. So that when they visit again later, they already have memories and perceptions as well as emotional reactions that assess a company or retail they have visited.

According to Schmitt (2013), the Marketing Act strategy is designed to create a customer experience that is related to body movements or, in other words, the movements and interactions that arise. Act Experience includes flesh related to the body, not only bringing sensations and perceptions about the outside world, but motor action (machine action) also fully works, which can cause interaction because it is closely related to the physical behavior of the lifestyle and social of the party. -interacting parties. The view that the interaction media is related to the experience in the learning program and followed by non-verbal behavior that cannot be separated and in the act of experience can also lead to self-perception of the learned behavior that causes the experience of interacting.

Schmitt (2013), experience is events that have a personal impression, which occurs in response to or as a result of the presence of stimuli or stimuli (for example, stimuli provided by marketing efforts, both before and after). after purchase). The experience involves the whole of life and is often the result of direct observation or participation in an event, whether real, in the form of a dream, or virtual. Usually, Experience does not happen by itself but must be triggered. Therefore, marketers must provide or create the right environment and settings to produce the expected Customer Experience.

Klaus and Maklan (2013) developed a construct of the Experience Quality (EXQ) concept model to assess experience quality and explore its impact on important marketing outcomes such as customer satisfaction, repeat purchasing behavior, and loyalty intentions.

\section{The Relationship between Destination Attributes and Return Visit Interest}

According to Muljadi (2010) in Mayasari and Budiatmo's research (2017) states that there are three important aspects of tourism products so that potential tourists visit, namely tourist attractions (tourist attractions), ease of reaching tourist destinations (accessibility), and facilities available in the area. A tourist destination (amenity). Hasan (2015) states that tourists' point of view considering all forms of visit, the product must be designed in a package consisting of tangible or intangible components in the form of services and activities at the destination must be felt by tourists as an experience that is following market prices. There are at least five components that must be considered when making a tourism product offer: attractions and environment, facilities and services, accessibility, destination image, and price.

The results of research conducted by Veronique (2015), Nusantini (2016), Mayasari and Budiatmo (2017) show that destination attributes influence the interest of returning tourists. Thus, a hypothesis can be proposed, namely:

H1: Destination attribute affects Revisit Interest.

\section{Relationship between Experience Quality and Return Visit Interest}

According to Rini (2016), quality of experience is defined as a consumer's assessment of the overall experience felt when consuming the products and services offered. Experience is more than just getting what products consumers want, but also on all events and activities that are part of business processes in an organization, such as the design of the environment, location, staff service, and how employees respond, as well as how consumers feel when they get service. The overall experience quality felt by consumers/visitors will form a perceived value to make a return visit. Research conducted by Boit, JC (2013), Marinkovic, et al., (2014), Limono and Semuel (2014), Mayasari and Budiatmo (2017), Ajeng and Finardi (2016) shows that experience quality has a positive effect on return visit interest. Based on the explanation above, a hypothesis is proposed, namely:

H2: Experience quality affects return visit interest

\section{RESEARCH METHODS}

The research period starts from March 2019 to January 2020. This research process begins with identifying problems at the research site, formulating problems, and collecting basic theories to strengthen the foundation of each variable. Furthermore, the preparation of methods in data collection, preparation of instruments to testing techniques is carried out. The research was conducted at the Lembang Floating Market, located in West Lembang Regency. The object of this research is a visitor who is visiting the Floating Market Lembang. 


\section{Population and Research Sample}

The population in this study are tourists who are visiting the Floating Market Lembang-floating Market Visitors. The sampling technique in this study used a convenience sampling sample. Convenience sampling is a sample considering convenience, which is a sampling technique based on convenience or coincidence. In this study, data were collected through field research. Field collection data were collected using a questionnaire. According to Noor (2015), a questionnaire is a collection technique by conducting or distributing a list of questions to respondents by responding to the list of questions. The distribution of questionnaires is intended for visitors to the Lembang Floating Market.

\section{Data analysis method}

According to Ghozali (2014), the data analysis method in this study uses component or variance-based Structural Equation Modeling (SEM), where the data processing uses the Smart-Partial Least Square (SmartPLS) version 3.0 program. PLS (Partial Least Square) is a model of variance-based SEM. PLS is intended for causal-predictive analysis in situations of high complexity and low theoretical support.

\section{RESULTS AND DISCUSSION}

\section{a. Hypothesis Testing Results (Estimated Path Coefficient)}

The estimated value for the path relationship in the structural model must be significant. The significance value for this hypothesis can be obtained by using the bootstrapping procedure. To see the significance of the hypothesis by looking at the parameter coefficient values and the T-statistical significance value in the bootstrapping report algorithm. In finding the significance, it can be seen from the T-table at an alpha of 0.05 $(5 \%)$.

Table 1. Hypothesis Testing Results

\begin{tabular}{lccccc}
\hline & $\begin{array}{c}\text { Original } \\
\text { Sample }\end{array}$ & $\begin{array}{c}\text { Standard } \\
\text { Deviation }\end{array}$ & T Statistics & $\begin{array}{c}\text { P } \\
\text { Values }\end{array}$ & Information \\
\hline $\begin{array}{l}\text { Destination Attributes } \rightarrow \\
\text { Return Visit Interest } \\
\begin{array}{l}\text { Experience Quality } \rightarrow \\
\text { Return Interests }\end{array}\end{array}$ & 0.696 & 0.063 & 10.937 & 0.000 & $\begin{array}{c}\text { Positive - } \\
\text { Significant } \\
\text { Positive- } \\
\text { Significant }\end{array}$ \\
\hline
\end{tabular}

Source: PLS Output, 2020

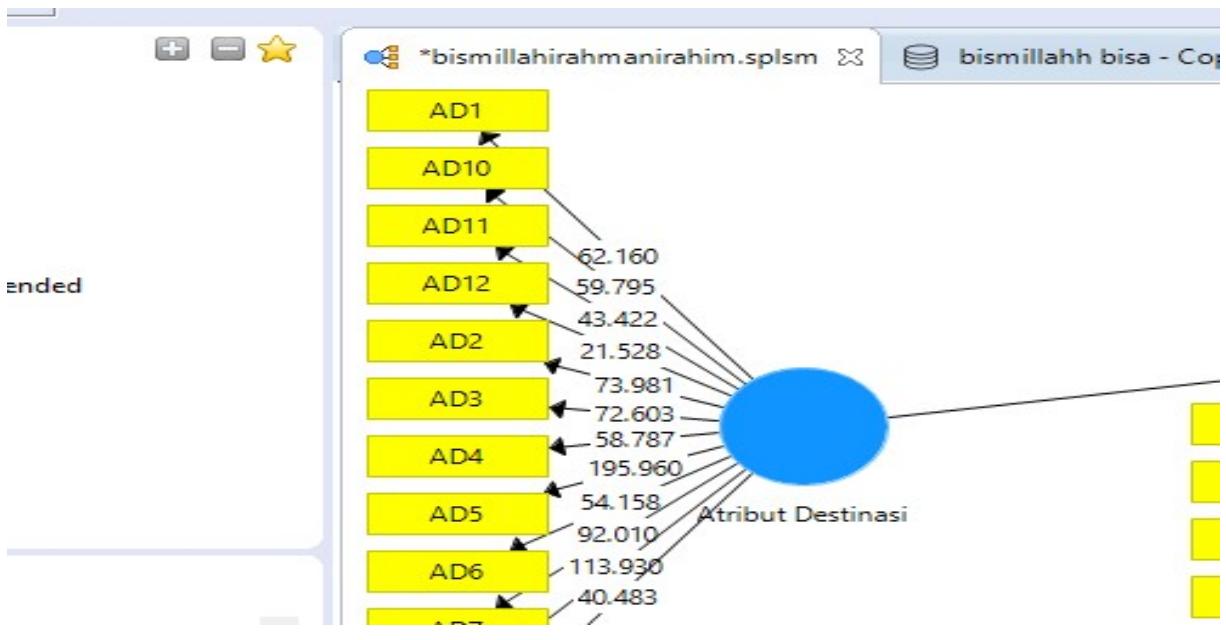

Figure 1. Bootstrapping Test Results

Source: PLS Output, 2020

\section{The effect of destination attributes on return visits}

Based on the hypothesis test in this study, the results of the T-statistic value were 5.027, the original sample value was 0.729 , and the $P$ Values value was 0.000 . The original sample value shows a positive value, and the P Values value shows less than 0.05 . This result shows that the destination attribute has a positive and 
significant effect on return visit interest. It means that if the destination attributes are complete, it will increase the interest in revisiting the Lembang floating market. It can be explained by indicators measuring destination attributes. It can be seen that of the twelve indicators, all statements affect destination attributes on return visit interest.

Destination attributes have a significant positive effect on return visit interest. If the destination attribute, it can increase the intention to repurchase. Attributes that have a dominant influence as a shaper of tourist perceptions are the attributes of the atmosphere. The real purpose of tourists traveling is to find another atmosphere (ambiance) from their daily lives, such as tranquility, entertainment, and relaxation. Tourists can also mingle and interact with the local community. The results of this study are in line with research conducted by Nusantini (2016) and Mayasari and Budiatmo (2016), showing that destination attributes positively influence the interest of returning tourists.

\section{Effect of experience quality on return visit interest}

The hypothesis test showed that the results of the T-statistic value of 1.542, the original sample value of 0.225 , and the $P$ Values of 0.005 . The original sample value shows a positive value, and the $P$ Values value shows less than 0.05 ; this result shows that the quality of the experience has a positive and significant effect on the interest in returning visits. It indicates that the positive quality will increase the interest in returning visits. It can be explained by indicators measuring the quality of experience. It can be concluded that the quality of the experience carried out directly or indirectly to the visitors about the attitude of service when tourists visit or after visiting is good so that tourists can feel the quality of experience provided by the Lembang floating market manager with satisfaction. The quality of the experience also plays an important role in retaining customers, so that the manager must be able and serve customers so that visitors will have a good quality experience to create interest in returning visits. The results of this study are in line with research conducted by Veljko et al. (2014), Limono and Semuel (2014), Ajeng and Finardi (2016), showing that the quality of the experience affects the interest in return visits.

\section{CLOSING}

\section{Conclusion}

1. Destination attributes have a positive and significant effect on return visit interest. Destination attributes can increase repurchase intentions. Attributes that have a dominant influence as a shaper of tourist perceptions are the attributes of the atmosphere. The real purpose of tourists traveling is to find another atmosphere (ambiance) from their daily lives, such as tranquility, entertainment, and relaxation. Tourists can also mingle and interact with the local community.

2. The quality of the experience has a positive and significant effect on the interest in return visits. It indicates that the positive quality will increase the interest in returning visits. It can be explained by indicators measuring the quality of experience. It can be concluded that the quality of the experience carried out directly or indirectly to the visitors about the attitude of service when tourists visit or after visiting is good so that tourists can feel the quality of experience provided by the Lembang floating market manager with satisfaction. The quality of the experience also plays an important role in retaining customers, so that the manager must be able and serve customers so that visitors will have a good quality experience to create interest in returning visits.

\section{Suggestion}

1. It can be suggested by the company or the manager of the Lembang Floating Market to expand the parking conditions provided for visitors.

2. It can be suggested that the company or the manager of the Lembang Floating Market add a new menu and maintain the existing flavors and update the design to create a new atmosphere so that visitors will visit again.

3. For companies or managers of Floating Market Lembang, please pay attention again to create a new atmosphere so that visitors can feel the difference in character during their next visit.

4. For companies or managers of the Lembang Floating Market, please maintain the existing ones and reevaluate in terms of service because most visitors like to fill their spare time for recreational tourism

5. Floating Market Lembang is expected to improve some of the existing attributes. For objects of attraction, it is necessary to strengthen several sectors that are already considered good. It is necessary to maintain the authenticity of natural tourism because almost everyone who visits wants to fulfill their physical needs, namely eliminating hunger, but they also want to get relaxation while there. In addition, it is also necessary to add several tourist attractions that support tourist visits. There is nothing wrong if the Lembang Floating 
Market is equipped with outbound activities, camping programs especially for foreign tourists, and other interesting activities.

6. Floating Market Lembang is expected to be able to improve some of the existing services. The level of service is more concerned, especially in handling complaints from visitors, it must be addressed as soon as possible, a suggestion box is provided so that each guest's input and complaints can be handled specifically. Maintain a free drink service for visitors because it will foster interest in making return visits.

\section{REFERENCE}

Albarq, Abbas N. 2014. Measuring The Impact Of Online Word Of Mouth Ontourists Attitude And Intention To Visit Jordan: An Emperical Study. International Business Research; Vol. 7(1).

Boit, J. C. (2013). The role of destination attributes and visitor satisfaction on tourist repeat visit intentions to Lake Nakuru National Park, Kenya. Western Illinois University.

Chen, C., dan Tsai, D. 2007. How Destination Image And Evaluative Factors Affect Behavioral Intentions. Tourism Management.

Dinas Pariwisata dan Kebudayaan Provinsi Jawa Barat. (2018). Jumlah Wisatawan Mancanegara Dan Domestik Jawa Barat Tahun 2014-2018. Dinas Pariwisata dan Kebudayaan Bandung.

Dwyer, L., \& Kim, C. (2003). Destination competitiveness: Determinants and indicators. Current Issues in Tourism, 6(5), 369-414. https://doi.org/10.1080/13683500308667962

Dyki, Dirbawanto dan Endang Sutrasmawati. 2016. Pengaruh Customer Experience Dan Brand Trust Terhadap Customer Loyalty. Management Journal Universitas Negeri Semarang Vol. 5 No.1.

Faris, Nursani. A (2015). Pengaruh Customer Experience Quality Terhadap Revisit Intention Pada Kampung Gajah: Survei Terhadap Pengunjung Kampung Gajah. Journal Research. Universitas Pendidikan Indonesia.

Fitriyani, Endah. (2014). Upaya Meningkatkan Revisit Intention Tamu Melalui Retro Marketing di Savoy Homann Bidakara Hotel. Bandung: Program Studi Manajemen Pemasaran Pariwisata, Universitas Pendidikan Indonesia.

Gallan, A. S., Jarvis, C. B., Brown, S. W., \& Bitner, M. J. (2013). Customer positivity and participation in services: an empirical test in a health care context. Journal of the Academy of Marketing Science, 41(3), 338-356.

Genia Gede Limono Dan Hatane Semuel. (2014). Pengaruh Experience Quality Terhadap Behavioral Intention Dengan Perceived Value Sebagai Mediasi Pada Restaurant Sushi Tei Di Surabaya. Jurnal Program Manajemen Pemasaran, Universitas Kristen Petra.

Ghozali, Imam. (2016). Aplikasi Analisis Multivariate Dengan Program Ibm Spss 23. Semarang: Badan Penerbit Universitas Diponegoro.

Ghozali, Imam. 2014. Structural Equation Modeling Metode Alternatif DenganPartial Least Squares (PLS). Edisi 4. Badan Penerbit Universitas Diponegoro. Semarang.

Khaeril, K., Muis, M., Jusni, J., \& Madris, M. (2020). Daya Saing Tujuan Wisata: Kajian Pustaka Sistematis. Indonesian Journal of Tourism and Leisure, 1(2), 103-117.

Klaus, Phil., Maklan, Stan., (2013). Towards A Better Measure Of Customer Experience, International Journal Of Market Research, Vol 55, Pp 227-246.

Kotler, Philip And Kevin Lane Keller. (2016). Marketing Management, 15 the edition New Jersey: Pearson Pretice Hall, Inc.

Kuo, Ying-Feng, Tzu-Li Hu, Shu-Chen Yang. (2013). Effects of inertia and satisfaction in female online shoppers on repeat-purchase intention. (The moderating roles of wordof-mouth and alternative attraction). Managing Service Quality, 23 (3), 168-187

Lin, C.H. (2012). Effects of Cuisine Experience, Psychological Well-Being, And Self-Health Perception on the Revisit Intention of Hot Springs Tourist. Journal of Hospitality \& Tourism Research, 38, 1-22.

Marinkovic, Veljko Et Al. (2014). "The Antecedents Of Satisfaction And Revisit Intentions For Full-Service Restaurants”. Marketing Intelligence \& Planning. 32, (3), 311-327.

Mayasari, W. M., \& Budiatmo, A. (2016). Pengaruh atribut produk wisata dan word of mouth terhadap keputusan berkunjung pada objek wisata taman margasatwa semarang. Jurnal Ilmu Administrasi Bisnis, 5(4), 501-509.

Mccoll-Kennedy, Janet R., Gustafsson, Anders., Jaakkola, Elina., Klaus, Phil., Radnor, Zoe Jane., Perks, Helen., Friman, Margareta., 2015, Fresh Perspectives On Customer Experience, Journal Of Services Marketing, $29(6 / 7), 430-435$.

Nayon, G. R. (2020). Pengaruh Experience Quality Terhadap Behavioral Intention Melalui Perceived Value Pada Wisata Kebun Teh Gunung Gambir DI Kabupaten Jember, (Skripsi, Fakultas Ekonomi dan Bisnis Universitas Jember). 
Nusantini, Ni L.A., (2016). Atribut Destinasi Yang Mempengaruhi Loyalitas Wisatawan Berkunjung Ke Kawasan Sanur. Jumpa, 2 (2).

Noor, Juliansyah. (2015). Metodologi Penelitian. Jakarta: Kencana.

Osti, L., Disegna, M., dan Brida, J.G. (2012). Repeat Visit And Intentions To Revisit A Sporting Event And Its Nearby Destinations. Journal Of Vacation Marketing, 18, 31-42

Palli, G. J. \& Mamilla, R. (2012). "Students' Opinions of Service Quality in the Field of Higher Education". Journal of Scientific Research. 3 (4), 430-438.

Pelu, I. E. A., Kurniawan, R., \& Akbar, W. (2019). Pengembangan wisata syariah dalam mendorong pertumbuhan ekonomi daerah (studi wisata halal Nusa Tenggara Barat).

Permana, D. (2018). Tourist's re-visit intention from perspective of value perception, destination image and satisfaction.

Qomariyah, Nor (2017). Marketing Attractiveness Dan Minat (Intention) Mempengaruhi Destination Image Desa Wisata Lempur: Suatu Kajian Pustaka. Prosiding Seminar Journal Nasional Aimiisbn: 1234-567890-12-1 Jambi, 27-28 Oktober.

Reisinger, Yvette. (2009). International Tourism: Cultures And Behavior. Oxford: Elsevier Ltd.

Safitri, K. (2017). Analisis Pengaruh Customer Experience dan kepuasan konsumen terhadap minat beli ulang di Storia Caffe MMXVI. Jurnal Terapan Manajemen dan Bisnis, 3(1), 195532.

Schmitt, Bernd. 2013. The Changing Face of the Asian Consumer: Insights and Strategies for Asian Markets. United Kingdom: Edward Elgar Publishing Limited

Senjaya, Vivie. (2013). Pengaruh Customer Experience Quality Terhadap Customer Satisfaction \& Customer Loyalty Di Kafe Excelso Tunjungan Plaza Surabaya: Perspektif B2C. Jurnal Manajemen Pemasaran Petra, 1 (1)

Undang-Undang Republik Indonesia Nomor 10 Tahun 2009 Tentang Kepariwisataan.

UNWTO. (2013). UNWTO Tourism Highlight 2013 Edition. Madrid, Spain ISBN: 978-92-844-1311-9.

Veronique Gaelle Ngo Ndjehemle I Likoum. (2015). Destination Image, Destination Attribute And Tourist Intention To Revisit And Recommend: An Application In Sanaga Maritine-Cameroon. Journal Institute Of Graduate Studies And Research In Partial Fulfillment Of The Requirements For The Degree Of Master Of Sciencein Tourism Management Eastern Mediterranean University Gasimağusta, North Cyprus.

Yuniawati, Yeni Dan Finardi, Ajeng Dewi Indriyani. (2016). Pengaruh Customer Experience Terhadap Revisit Intention Di Taman Wisata Alam Gunung Tangkuban Perahu, 6(1), 983-94. Retrieved From Tourism And Hospitality Essentials (THE) Journal. 